\title{
Hepatitis C Virus in mainland China with an emphasis on genotype and subtype distribution
}

\author{
Yu Zhang ${ }^{1,2}$, Li-Min Chen ${ }^{1,2,3}$ and Miao He ${ }^{1,2^{*}}$
}

\begin{abstract}
Due to the low fidelity of the RNA-dependent RNA polymerase, Hepatitis C virus (HCV) mutates quite frequently. There are seven genetically divergent genotypes (GTs) distributed in the world, each of which contains several closely related subtypes. The peer-reviewed literatures reporting the prevalence rate of HCV GTs in Chinese hospitalized patients were identified by systematic searching of three electronic databases, and the prevalence rates were pooled through 137 qualified studies. The significant difference between HCV GT and HCV viral load and severity of hepatitis were analyzed under Chi-squared or Fisher's exact test. Data from epidemiological studies on hospitalized patients demonstrated that HCV GTs 1-6 have been found in China, of which $1 \mathrm{~b}(62.78 \%(95 \% \mathrm{Cl}: 59.54-66.02 \%))$ and 2a (17.39\% (95\% Cl: 15.67-19. $11 \%))$ are the two predominant subtypes. HCV GTs and subtypes exhibits significant regional divergence. In North, Northwest, Northeast, East (except Jiangxi province) and Central China (except Hunan province), HCV-1b, 2a remain the two predominant subtypes; South China shows the most abundant genetic diversity that 14 subtypes were found, and HCV-3 in the Southwest China remains higher prevalent subtype than the other regions. In addition, co-infection in Liaoning province of Northeast China is the most diverse with 10 co-infection types, and Tibet has the highest rate of co-infection. The associations between HCV GTs and patients group, severity of illness and antiviral treatment efficacy were also discussed in this review.
\end{abstract}

Keywords: HCV genotype, Subtypes, Distribution, Co-infection, Population demographics, Antiviral treatment efficacy

\section{Background}

Hepatitis $\mathrm{C}$ virus (HCV) is a globally distributed hepatic virus with an estimated 130 to 150 million people (2 to $3 \%$ of the world's population) chronically infected world widely [1, 2]. It has been reported that by $2025, \mathrm{HCV}$ related mortality will be tripled [3]. HCV infection constitutes over $70 \%$ of post-transfusion hepatitis (PTHC), and is one of the leading causes of chronic liver disease, which usually results in liver cirrhosis (LC), liver failure and hepatocellular carcinoma (HCC) within 20 to 30 years following infection [4-6]. HCV incidence in China was $0.06 \%$, however, in some area such as in Fujian, reached as high as $6.01 \%$ in 2010 [7]. HCV infection has become the second major type of viral liver disease only next to

\footnotetext{
* Correspondence: messa1022@126.com

'Institute of Blood Transfusion, Peking Union Medical College, Chinese

Academy of Medical Sciences, Chengdu 610052, China

${ }^{2}$ Sichuan Blood Safety and Blood Substitute, International Science and

Technology Cooperation Base, Chengdu 610052, China

Full list of author information is available at the end of the article
}

Hepatitis B virus (HBV) infection in China [8], and exhibits great threat to public health.

Hepatitis $\mathrm{C}$ virus (HCV) was classified into genus Hepacivirus of family Flaviviridae [6]. Like other positivestranded RNA viruses, the HCV genome encodes a single polyprotein with approximately 3000 -amino-acids in length with the following order: 5'-C-E1-E2-p7-NS2-NS3NS4A-NS4B-NS5A-NS5B-3' [9], and flanks with 5' and 3' untranslated regions, which consists of 341 and 27 bases, respectively [10]. HCV genome has high genetic heterogeneity with as much as $30 \%$ of sequence divergence [11]. Based on the sequence divergence, HCV was classified into seven different genotypes (GTs) and more than 90 subtypes [6,12]. The greatest genetic diversity was observed within HCV-6, with 24 subtypes (6a-6xa) being classified [13, 14].

In China, HCV GT distribution has been associated with various geographical and demographic characteristics. Due to the increasing mobility of the population 
and different transmission routs, HCV GTs distribution changed gradually and co-infection with multiple subtypes as well as genetic recombinant appeared frequently in some regions. Most recently, three new subtypes have been characterized in China: HCV-1b-2a, 1b-2 k and 6d$6 \mathrm{k}$ [15]. Since there is a paucity of data from large-sample study of HCV GT distribution in China, this review aims to describe the most comprehensive distribution of $\mathrm{HCV}$ GTs in mainland China in order to facilitate personalized treatment and to further understand the virology of $\mathrm{HCV}$ for vaccine and antiviral drug development in China.

\section{Methods}

Literature search

The literature search on HCV GT detection among clinical cases in mainland China was conducted using China National Knowledge Infrastructure (CNKI), PubMed and Wanfang Data (a Chinese professional academic database developed by Wanfang data limited-liability Company) with the key words "HCV" or "Hepatitis C virus"; "genotype" or "subtype", "sequencing" or sequence analysis"; "transfusion transmitted disease" and "China" or "Mainland China". No language restrictions were applied.

\section{Literature selection and data extraction}

The inclusion criteria included: 1) The study was conducted only in mainland China (Hong Kong, Taiwan and Macao were excluded); 2) Studies involving the HCV genotype and (or) subtype distribution; 3) The study object were hospitalized patients; 4) Studies with clear sample size.

The exclusion criteria were as follows: 1) studies without exact sample size, publication year and methods; 2) Overlapping or paradoxical studies: data from literature were repeat or inconsistent between the context; 3) The study objects were blood donors or intravenous drug user; 4) HCV GTs prevalence rate in patients with HIV/ HCV co-infection; 5) Comments, reviews or conference abstracts. When investigating the trends of HCV GT spatio-temporal distributions, literatures without exact study year were not included.

\section{Statistical analysis}

Pooled results for the prevalence rate of HCV GTs and corresponding $95 \%$ CIs by metan command in Stata 12.0 were used to assess the HCV GTs distribution status among hospitalized patients in China. The \% of GT in each study counted by the weighted method that the contribution of each study was determined by number of patients in the individual studies. The time trend of $\mathrm{HCV}$ prevalence rate, and the significant difference between HCV GT and HCV viral load and severity of hepatitis was performed using SPSS Statistics 17.0 based on Chi-squared or Fisher's exact test of crosstabs, and $P$ value $<0.05$ represents statistical significance.

\section{Results \\ HCV GT distribution \\ A profile of HCV GT data}

Related data were collected: 193 studies [6-8, 12, 13, 16-203] considering methods used for HCV genotyping (Table 1); 137 clinical studies [7, 8, 12, 13, 16-146, 202, 203] with a total of 19712 HCV hospitalized cases considering prevalence rate of HCV subtypes [Fig. 1].

Commonly used molecular biology methods for $\mathrm{HCV}$ genotyping include DNA sequence assay (a gold standard), type specific primers amplification method, restriction fragment length polymorphism (RFLP), gene chip assay, and probe hybridization. Multiple methods targeting different regions of the HCV genome have been used for classifying GTs. The most accurate method is to sequence an appropriate coding region that varies enough for phylogenetic analysis to distinguish genotypes and subtypes [204, 205]. Although the 5' untranslated region (5'UTR) has most often been used by clinical laboratories for routine genotyping considering its high level of conservation, the 5'UTR is limited in its ability to discriminate GT 6 from GT 1 and subtypes within GTs 1, $2,3,4$, and $6[14,206]$. Nowadays, the three most commonly used regions for determining the HCV GT and subtypes are Core, E1, and NS5B [14, 207] with high accuracy and sensitivity.

\section{HCV GT distribution among clinical cases in mainland China}

The dominant HCV GTs in most Asian countries are HCV-1, 3 [208]. Although six GTs (GTs 1 to 6), 24 subtypes (subtypes 1a, 1b, 1c, 2a, 2b, 2i, 2f, 2 k, 3a, 3b, 3 k, 4, 5a, 6a, 6b, 6d, 6e, 6 g, 6 h, 6 k, 6n, 6u, 6v, and 6w), and a number of unassigned HCV variants have been detected in China, over 95\% of these isolates belong to five major subtypes: 1b, 2a, 3a, 3b, and 6a [12, 177, 209-214].

The prevalence rate of HCV GTs in various regions of mainland China was pooled, and corresponding 95\% CIs was also further tabulated (Table 2). Although HCV GTs 1-6 have been found in China, GTs $1 \mathrm{~b}$ and $2 \mathrm{a}$ were the two major HCV subtypes, accounting for $62.78 \%$ (95\% CI: $59.54-66.02 \%)$ and $17.39 \%$ (95\% CI: 15.67-19.11\%), respectively. In $70 \%(22 / 30)$ of provinces, HCV-1b, $2 \mathrm{a}$ are still the most prevalent. The major GTs in Jiangxi, Guangdong, Hunan and Guangxi were 1b, 6a, while in Yunnan, Sichuan, Guizhou and Chongqing were 1b, $3 b$. In Yunnan Province, $3 \mathrm{~b}$ and $1 \mathrm{~b}$ was the predominant HCV subtypes. HCV GT distribution also exhibits significant region divergence (Fig. 2). The major subtypes in North China, Northwest and Northeast were $1 \mathrm{~b}$ and 2a, although 1a, 1c, 2b, 2c, 2i, 2 k, 3a, 3b, 3 k, 4, 6a were also identified. In East and Central China, HCV-1b, 2a 
Table 1 Methods used for HCV genotyping in mainland China

\begin{tabular}{|c|c|c|c|}
\hline Region & Province & Genotyping method & Amplified fragment \\
\hline Central China $^{1 *}$ & Hunan, Hubei, Henan & $\begin{array}{l}\text { Nested-PCR and sequence analysis, PCR-RDB, GT- } \\
\text { specific primers PCR method, gene chip assay }\end{array}$ & $\begin{array}{l}\text { Core and E1, NS5B and/or Core-E1, } \\
\text { NS5B, 5'UTR, core }\end{array}$ \\
\hline East China $^{2 *}$ & $\begin{array}{l}\text { Shandong, Jiangsu, } \\
\text { Anhui, Jiangxi, Fujian, } \\
\text { Shanghai, Zhejiang }\end{array}$ & $\begin{array}{l}\text { Nested-PCR and sequence analysis, RFLP, GT- } \\
\text { specific primers PCR method, gene chip assay, } \\
\text { Genotyping detection kit (DNA sequence assay), } \\
\text { PCR-RDB, Micro plate nucleic acid hybridization- } \\
\text { ELISA technique, LiPA }\end{array}$ & $\begin{array}{l}5^{\prime}-\text { UTR, core, NS5B } \\
\text { and/or core-E1, 5'-UTR and/or NS5B, } \\
\text { NS5B and C/E2, core and NS5B and } \\
5^{\prime}-U T R, E 2, \text { NS5B and E2 }\end{array}$ \\
\hline South China ${ }^{3 *}$ & $\begin{array}{l}\text { Guangdong, Guangxi, } \\
\text { Hainan }\end{array}$ & $\begin{array}{l}\text { Nested-PCR and sequence analysis, GT-specific } \\
\text { primers PCR method, gene chip assay, PCR - RDB, } \\
\text { LiPA }\end{array}$ & $\begin{array}{l}\text { NS5B and E1, core and NS5B, E1, NS5B, 5'-UTR and } \\
\text { NS5B }\end{array}$ \\
\hline North China ${ }^{4 *}$ & $\begin{array}{l}\text { Beijing, Shanxi, } \\
\text { Tianjin, Hebei, IM }\end{array}$ & $\begin{array}{l}\text { RFLP, Nested-PCR and sequence analysis, GT- } \\
\text { specific primers PCR method, gene chip assay, PCR } \\
\text { fluorescent probe method }\end{array}$ & Core, C/E1, 5'-UTR \\
\hline Southwest $^{5 *}$ & $\begin{array}{l}\text { Sichuan, Yunnan, } \\
\text { Chongqing, Guizhou }\end{array}$ & $\begin{array}{l}\text { gene chip assay, RFLP, Nested-PCR and sequence } \\
\text { analysis, PCR-RDB, Type specific probe hybridization } \\
\text { method }\end{array}$ & $\begin{array}{l}\text { 5'-UTR, 5'UTR-core and E1-E2 and NS5B, } \\
5^{\prime} \text { NCR-C and NS5B, core/E1 and } \\
\text { NS5B, E1/E2 and NS5B, 5'-UTR and Core, } \\
\text { core and E1, core, C/E1, NS5B }\end{array}$ \\
\hline Northwest ${ }^{6 *}$ & Gansu, Sha anxi, Xinjiang & $\begin{array}{l}\text { Nested-PCR and sequence analysis, RFLP, PCR- } \\
\text { RDB,GT-specific primers PCR method,LiPA, } \\
\text { restriction endonuclease cleaving method }\end{array}$ & E1 and NS5B, $5^{\prime} \mathrm{NCR}, \mathrm{NS} 5 \mathrm{~B}$ \\
\hline Northeast $^{7 *}$ & $\begin{array}{l}\text { Liaoning, Heilongjiang, } \\
\text { Jilin }\end{array}$ & $\begin{array}{l}\text { RFLP, Nested-PCR and sequence analysis, PCR - } \\
\text { RDB, type-specific primers PCR method, gene chip } \\
\text { assay }\end{array}$ & NS5, Core, 5'UTR, C and E1 and NS5 \\
\hline
\end{tabular}

PCR-RDB: Polymerase chain reaction-reverse dot blot; RFLP: Restriction fragment length polymorphism LiPA: Line probe hybridization method

$1 *$ See reference $[7,16-30,131,155,193]$

$2^{*}$. See reference $[6,8,31-67,132-139,147-150,156-166,199,201]$

$3^{*}$. See reference $[12,13,67-82,167-178,202]$

$4^{*}$. See reference $[83-89,145,151,152,179-182,203]$

$5^{*}$. See reference $[82,90-102,153,179,188-192,194-198]$

$6^{*}$. See reference [103-120, 141-144, 146, 184-187]

$7 *$. See reference $[121-130,140,154,183]$

remain the two predominant subtypes except Jiangxi and Hunan province with the popular subtypes $1 \mathrm{~b}$ and 6a. In Southwest and South China, HCV-1b, 3b/6a was the predominant subtype. South China region showed the most abundant genetic diversity with 14 subtypes (1a, 1b, 1c, 2a, 2b, 2f, 3a, 3b, 4, 5a, 6a, 6d, 6e, 6n) being found, and HCV-3 in the Southwest remains higher prevalent subtype than other regions, which was consistent with previously published studies [212, 215].

HCV GT distribution reported by various Chinese regions is experiencing a remarkable change over time. An annual decrease of $1 b, 2 a$, and an increase of GT $3 a, 3 b$, $6 \mathrm{n}$ and $6 \mathrm{a}$ were reported in Henan, Jiangsu, Zhejiang, Chongqing, Tianjin and Yunnan $[13,16,25,90,136$, 152, 191, 216, 217]. We also screened qualified literatures from the hospitalized cases, and three periods (before 2005; 2005-2010; after 2010) were divided to summary respective prevalence rate of HCV GT. Comparison of prevalence rate over time was then performed to get the changing trend of HCV GT distribution. Our results showed that in Southwest and South China, HCV GT distribution experienced a significant change $(P<0.05)$ (Table 3$)$ that the proportion of subtypes $1 \mathrm{~b}$, 2a were decreasing and yet GT 3 were increasing over time. In addition, HCV subtype 4, 5, 6v, 6d, 6u have also been found in some areas of China in recent years [191, 210, 211, 213, 218]. This changing trend may result from the increasing population mobility, various transmission routes, and the improved sensitivity and specificity of testing methods.

\section{HCV GT characteristics of co-infection in China}

Presence of multiple HCV subtypes, increasing of population mobility and drug abusers, more convenient use of hemodialysis and improved detection methods increase the incidence of reported co-infection with multiple subtypes and genomic recombination. Till now, at least 5 subtypes of co-infection have been reported in China [170, 219].

In recent years, HCV GTs exhibit an increased percentage of co-infection, of which the most common in China was $1 \mathrm{~b} / 2 \mathrm{a}$ co-infection, and GTs $2 \mathrm{a} / 2 \mathrm{~b}$ and $1 \mathrm{~b} / 2 \mathrm{~b}$ co-infection were occasionally reported, which may affect the host immune responses and treatment outcomes [220-222]. It was reported that among 1450 HCV RNA positive plasma (serum) samples collected 
Records identified through database searching (CNKI Wanfang Pubmed, $n=747$ )

Title screen

Duplicates $(n=123)$

Records after duplicates removed $(n=624)$

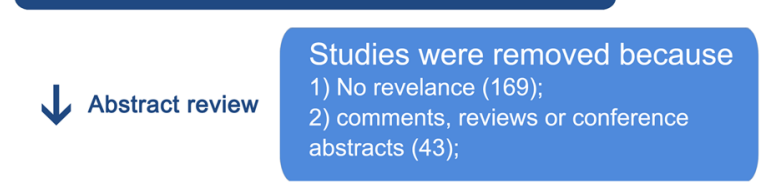

Relevant studies $(\mathrm{n}=412)$

Studies were removed because

1) Not Chinese mainland (26);

2) The data was paradoxical or repeated (31);

3) The publication year was not indicated (2);

4) studies without exact sample size and

method(160)

Eligible studies $(n=193$

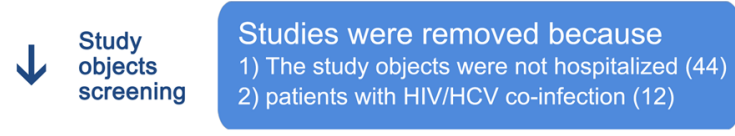

Clinical studies used in this review ( $n=137)$

Fig. 1 Flow diagram of summary of search strategy

randomly from general and infectious disease-specialized hospitals of the capital city from all provinces (except Taiwan), municipalities (except Chongqing), and autonomous regions (except Xinjiang), 11 was reported as $\mathrm{HCV}$ co-infection. These co-infection with multiple subtypes involved $1 \mathrm{~b}, 2 \mathrm{a}$ and $6 \mathrm{a}$, of which $1 \mathrm{~b} / 2 \mathrm{a}$ was the most common, accounting for $81.8 \%(9 / 11)$ and followed by $6 \mathrm{a} / 2 \mathrm{a}$ and $6 \mathrm{a} / 1 \mathrm{a}$, which is also the first time for $\mathrm{HCV}$ co-infection in China that the GT 6a was found [223]. Patients who repeatedly received blood, used to share needles as intravenous drug users (IDUs) and routinely performed dialysis contributed significantly to multiple HCV genotypes/subtype co-infection in China [222, 224]. According to our statistical analysis, co-infection in Liaoning province of Northeast China is the most diverse with 10 co-infection types, and Tibet has the highest rate of co-infection, which might suggest that there had a relatively high proportion of patents who would be a repeated recipient, an IDU, or a dialysis patient. In addition, it was reported that HCV triple infections kept a relatively high percentage in Gansu, of which GTs $1 \mathrm{a} / 1 \mathrm{~b} / 2 \mathrm{a}$ or $1 \mathrm{a} / 1 \mathrm{~b} / 2 \mathrm{c}$ were more popular, accounting for $20.6 \%(14 / 68)$ infections [186].

In addition, HCV subtype 6a was most common in patients with $\mathrm{HIV} / \mathrm{HCV}$ co-infection, and was mainly spread through intravenous drug use $[225,226]$.
HCV GTs and different population demographics

HCV GT distribution usually varied in different populations such as in blood donors, IDUs, hemodialysis patients (HDs) and hepatitis patients. The distribution pattern changes with the change of transmission modes [227]. Generally, transfusion transmitted $\mathrm{HCV}$ were strongly associated with subtypes $1 \mathrm{~b}$ and $2 \mathrm{a}[89,180,181]$. Encouragingly, the paid blood donation is not common in China with the implementation of the Blood Donation Law in 1998. In voluntary blood donors, GTs $1 \mathrm{~b}$ and $2 \mathrm{a}$ account for the highest proportion [228], and HCV GT distribution exhibits significant geographical difference: The most common GTs in Shanxi, Henan, Jiangsu, Anhui, Shanghai, Shaanxi, Hebei and Xinjiang are $1 \mathrm{~b}$ and $2 \mathrm{a}$; the prevalent GTs in Guangdong and Fujian Province are 1b and 6a; the dominant GTs in Chongqing and Yunnan are 3a and 2a/ 3b; GTs $1 \mathrm{~b}, 1 \mathrm{a}$ and $1 \mathrm{~b}, 3 \mathrm{~b}$ are most common in Guangxi and Qinghai, respectively. In addition, the proportion of subtypes $1 \mathrm{~b}$ and $2 \mathrm{a}$ in volunteers decreased in recent years, and yet subtypes 3 and 6 increased [179, 229]. Some reasons may explain this GT shift: 1) Increasing of drug abuser and commercial sex activity resulted in transmission from high risk population to general population; 2) Upgrade of genotyping methods accompanied by new HCV GTs and subtypes. Among IDUs, HCV-1a, 1b, 2a, $3 \mathrm{a}, 3 \mathrm{~b}, 6 \mathrm{a}, 6 \mathrm{n}$ and $6 \mathrm{u}$ have been found, of which HCV-6a and $3 \mathrm{~b} / 3 \mathrm{a} / 1 \mathrm{~b}$ were the most popular GTs. In HD patients, the prevalence of genotype 1 is the highest, and HCV GTs among HDs are very complex with the co-infection accounting for a big proportion [224, 230, 231], which may be ascribed to long-term dialysis, repeatedly blood transfusion and iatrogenic factors. In addition, some cases of subtype $2 \mathrm{a}$ are found in individuals with high risk sexual behaviors, while $1 \mathrm{~b}$ was more popular in clinical cases [194, 232, 233].

According to statistic results, discrepancy results displayed the association between HCV GTs and gender, age in infected patients. Most studies showed no statistical difference between HCV GT and gender $[7,20,31,136,137,234]$, while the rest displayed significant difference, of which the proportion of subtype $1 b$ was higher in male than in female. And on the contrary, subtype 2a showed the opposite distribution [13, 32, $40,83,156]$. The reasonable explanation for this significant difference may be that different genders exhibit different immune response against HCV infections with different GTs. For the relationship between HCV GT and age, most studies reported no statistical difference. However, there were a few studies showed that GT 1 and 2 were more common in the older group while GT 3 and 6 in the younger group [78, 137, 235]. The reason may be ascribed to be that the transmission routs are more inclined to blood transfusion in the elder group and the main GTs were $\mathrm{HCV}-1$ and 2. While in the younger 
Table 2 HCV GT/subtypes distribution in mainland China

\begin{tabular}{|c|c|c|c|}
\hline Study location & Province & The dominated two GTs in each province & The other distributed GTs \\
\hline \multirow[t]{14}{*}{ East China } & \multirow[t]{2}{*}{ Shandong } & 1b 67.74\% (95\% Cl: 60.94-74.53\%) & \multirow[t]{2}{*}{$6 a, 1 a, 3 a, 3 b$} \\
\hline & & 2a $27.57 \%$ (95\% Cl: 22.76-32.38\%) & \\
\hline & \multirow[t]{2}{*}{ Jiangsu } & 1b 75.77\% (95\% Cl: 72.47-79.07\%) & \multirow[t]{2}{*}{$2 \mathrm{i}, 3 \mathrm{~b}, 3 \mathrm{a}, 1 \mathrm{a}, 6 \mathrm{a}, 2 \mathrm{~b}, 6 \mathrm{~h}, 1 \mathrm{c}, 6 \mathrm{~b}$} \\
\hline & & 2a $11.01 \%$ (95\% Cl: 8.77-13.25\%) & \\
\hline & \multirow[t]{2}{*}{ Anhui } & 1b 66.45\% (95\% Cl: 47.57-85.32\%) & \multirow[t]{2}{*}{$3 b, 3 a, 6 k, 1 a, 2 b$} \\
\hline & & 2a $16.52 \%$ (95\% Cl: 8.77-24.28\%) & \\
\hline & \multirow[t]{2}{*}{ Zhejiang } & 1b 67.95\% (95\% Cl: 56.70-79.20\%) & \multirow[t]{2}{*}{$3 \mathrm{~b}, 3 \mathrm{a}, 6 \mathrm{a}, 1 \mathrm{a}$} \\
\hline & & 2a 11.06\% (95\% Cl: 9.06-13.05\%) & \\
\hline & \multirow[t]{2}{*}{ Jiangxi } & 1b 70.28\% (95\% Cl: 52.38-88.19\%) & \multirow[t]{2}{*}{$2 a, 2 b, 3 a, 3 b$} \\
\hline & & 6a $21.82 \%$ (95\% Cl: 10.90-32.73\%) & \\
\hline & \multirow[t]{2}{*}{ Fujian } & 1b 66.17\% (95\% Cl: 33.93-98.4\%) & \multirow[t]{2}{*}{$3 b, 6 a, 3 a, 2 b, 6 b$} \\
\hline & & 2a 17.42\% (95\% Cl: 11.45-23.39\%) & \\
\hline & \multirow[t]{2}{*}{ Shanghai } & 1b 80.14\% (95\% Cl: 69.64-90.63\%) & \multirow[t]{2}{*}{$3 a, 3 b, 1 a, 6 n, 6 a$} \\
\hline & & 2a 13.28\% (95\% Cl: 8.22-18.35\%) & \\
\hline \multirow[t]{6}{*}{ South China } & \multirow[t]{2}{*}{ Guangdong } & 1b 63.91\% (95\% Cl: 58.48-69.34\% & $2 a, 3 b, 3 a, 1 a, 6 e, 6 n, 4,2 b, 5 a$ \\
\hline & & 6а 17.32\% (95\% Cl: 14.44-20.21\%) & $1 c, 2 f$ \\
\hline & \multirow[t]{2}{*}{ Guangxi } & 1b 56.46\% (95\% Cl: 50.73-62.20\%) & \multirow[t]{2}{*}{$3 b, 1 a, 2 a, 3 a, 6 d$} \\
\hline & & 6a 12.88\% (95\% Cl: 9.00-16.75\%) & \\
\hline & \multirow[t]{2}{*}{ Hainan } & 1b 62.50\% (95\% Cl: 51.32-73.68\%) & \multirow[t]{2}{*}{$3 a$} \\
\hline & & 2a $29.17 \%$ (95\% Cl: 18.67-39.67\%) & \\
\hline \multirow[t]{10}{*}{ North China } & \multirow[t]{2}{*}{ Beijing } & 1b $70.41 \%$ (95\% Cl: 65.95-74.87\%) & \multirow[t]{2}{*}{$1 \mathrm{a}, 2 \mathrm{~b}, 3 \mathrm{a}$} \\
\hline & & 2a 22.15\% (95\% Cl: 17.22-27.08\%) & \\
\hline & \multirow[t]{2}{*}{ Hebei } & 1b 46.56\% (95\% Cl: 40.69-52.44\%) & $1 a, 2 b, 3 a$ \\
\hline & & 2a 36.69\% (95\% Cl: 30.05-43.34\%) & \\
\hline & Shanxi & 1b 67.22\% (95\% Cl: 57.44-77.00\%) & $1 a, 3 a$ \\
\hline & & 2a 13.51\% (95\% Cl: 6.37-20.65\%) & \\
\hline & Tianjin & 1b 84.21\% (95\% Cl: 72.62\%-95.8\%) & \\
\hline & & 2a 13.16\% (95\% Cl: 2.41-23.91\%) & \\
\hline & Inner Mongolia & 1b 63.27\% (95\% Cl: 38.34-88.20\%) & $3 a, 1 a$ \\
\hline & & 2a 33.33\% (95\% Cl: 11.97-54.70\%) & \\
\hline Central China & Hunan & 1b 41.04\% (95\% Cl: 33.71-48.37\%) & $3 b, 2 a, 3 a, 5 a$ \\
\hline & & 6а 18.50\% (95\% Cl: 12.71-24.28\%) & \\
\hline & Hubei & 1b 74.08\% (95\% Cl: 66.69-81.47\%) & $3 b, 6 a, 3 a, 1 a, 2 b, 6 b$ \\
\hline & & 2a 12.68\% (95\% Cl: 8.91-16.46\%) & \\
\hline & Henan & 1b 78.57\% (95\% Cl: 62.47-94.66\%) & $6 a, 3 a, 3 b, 1 a$ \\
\hline & & 2a 14.26\% (95\% Cl: 5.71-22.8\%) & \\
\hline Southwest & Sichuan & 1b 78.84\% (95\% Cl: 73.01-84.66\%) & $2 a$ \\
\hline & & 3b 8.47\% (95\% Cl: 4.50-12.43\%) & \\
\hline & Yunnan & 3b 49.50\% (95\% Cl: 38.01-60.98\%) & $3 a, 2 a, 6 n, 6 a$ \\
\hline & & 1b 20.52\% (95\% Cl: 16.31-24.73\%) & \\
\hline & Tibet & 1b 49.63\% (95\% Cl: 41.27-58.0\%) & $1 a$ \\
\hline & & 2a 16.38\% (95\% Cl: -5.30-38.06\%) & \\
\hline & Guizhou & 1b 35.22\% (95\% Cl: 30.92-39.52\%) & $6 a, 3 a, 2 a, 1 a, 2 b, 6 d$ \\
\hline
\end{tabular}


Table 2 HCV GT/subtypes distribution in mainland China (Continued)

\begin{tabular}{|c|c|c|c|}
\hline & & 3b 21.93\% (95\% Cl: 18.22-25.65\%) & \\
\hline & Chongqing & 1b $32.21 \%(95 \%$ Cl: 25.04-39.38\%) & $2 a, 6 a, 3 a, 1 a, 6 b, 2 b, 3 k$ \\
\hline & & 3b 21.86\% (95\% Cl: 7.99-35.73\%) & \\
\hline Northwest & Shaanxi & 1b $50.74 \%$ (95\% Cl: 42.35-59.14\%) & $6 a, 3 a, 3 b$ \\
\hline & & 2a 40.39\% (95\% Cl: 32.15-48.62\%) & \\
\hline & Gansu & 1b $56.07 \%$ (95\% Cl: 49.91-62.23\%) & $1 c, 1 a, 2 c, 3 a, 2 b, 3 b$ \\
\hline & & 2a 26.74\% (95\% Cl: 16.44-37.03\%) & \\
\hline & Xinjiang & 1b 62.71\% (95\% Cl: 60.10-65.33\%) & $1 a, 3 a, 2 b, 3 b, 4,6 a$ \\
\hline & & 2a $18.10 \%$ (95\% Cl: 11.99-24.2\%) & \\
\hline & Qinghai & 1b 49.08\% (95\% Cl: 30.01-68.16\%) & $3 b, 3 a$ \\
\hline & & 2a $33.8 \%$ (95\% Cl: 26.84-40.76\%) & \\
\hline Northeast & Heilongjiang & 1b 48.46\% (95\% Cl: 41.29-55.62\%) & $2 c, 2 b, 1 a, 3 a$ \\
\hline & & 2a 37.73\% (95\% Cl: 28.82-46.65\%) & \\
\hline & Liaoning & 1b $44.87 \%$ (95\% Cl: 24.30-65.44\%) & $1 \mathrm{a}, 2 \mathrm{i}, 3 \mathrm{a}, 1 \mathrm{c}, 2 \mathrm{~b}, 3 \mathrm{~b}, 3 \mathrm{k}, 2 \mathrm{k}$ \\
\hline & & 2a 34.37\% (95\% Cl: 11.24-57.50\%) & \\
\hline & Jilin & 1b 56.44\% (95\% Cl: 50.51-62.38\%) & $2 b, 1 a, 3 a$ \\
\hline & & 2a 31.96\% (95\% Cl: 19.42-44.50\%) & \\
\hline
\end{tabular}

group, the patients were mainly infected by HCV-3 and 6 via intravenous drug abuse and high risk sexual behaviors. However, one study in 2012 showed that subtype 1 was found more often in younger patients $(<40)$ [125], and another report showed no statistical difference between HCV-2a and age [78]. In view of the above discrepancy results, a large-scale multiple-center study involved a wider area is needed to clarify the association between HCV GT and age or gender in China.

\section{HCV GTs and viral loads}

Many present studies were designed to determine the association between HCV GTs and viral loads in chronic hepatitis patients. It has been well known that HCV genotype/subtype together with viral load variations during treatment are very important to guide the therapeutic strategies and relapse rates [236]. However, many discrepant results were reported. Generally speaking, the higher HCV RNA loads would cause more severe liver damage with more obvious clinical manifestations [78]. The viral load in patients chronically infected with $\mathrm{HCV}$ is associated with GTs that the level of HCV RNA in HCV-1 patients is higher than that in GT non-1, and HCV-1 and 6 is higher than HCV-2 and 3 [52, 77, 78, 96, 152, 237], which might be due to more efficient viral replication of GTs 1 and 6 [238-240]. Some foreign studies also reported the similar results [241]. However, another study reported that among patients with high viral load in China, HCV 2a was more common than other GTs [113], while some foreign studies reported that genotype 3 or 4 were found to be significantly higher viral load as compared to other genotypes [242, 243]. In addition, higher levels of viral load were also seen in $\mathrm{HCV}$ co-infection [156]. Interestingly, some other studies found no significant correlation between HCV GTs and viral loads [31, 52, 78, 92, 101, 135, 153].

Considering these conflicting and complex results above, we extracted the qualified literature $[17,18,32$, $33,44,83,133,135,152,202,234,244]$ from the screened hospitalized patients to summary the related cases in mainland China among different GTs based on HCV RNA quantitative level $\left(<10^{6}\right.$ copies/ml indicates low viral load; $\geq 10^{6}$ copies $/ \mathrm{ml}$ indicates high viral load), and performed the statistical analysis of between them. The overall result showed significant statistical difference $(P<0.05)$, which indicate HCV GT is associated with $\mathrm{HCV}$ viral load. No significant difference between subtypes $2 \mathrm{a}$ and $3 \mathrm{a}$ was found, and the significant difference was found in the other subtypes (Table 4) that HCV RNA level with subtypes $1 b$ and $6 a$ was higher than $2 \mathrm{a}, 3 \mathrm{a}$ and $3 \mathrm{~b}$. Various factors may be taken into account: 1) Different viral replication ability among various subtypes; 2) Regional GT distribution difference; 2) $\mathrm{HCV}$ infection time was not restricted exactly and identified in the same or similar stage. Since high viral load is difficult to treat than low viral load, we suggest precise mechanism study should be performed to ascertain the correlation between HCV genotypes and viral load and to further design the therapeutic strategies.

\section{HCV GTs and severity of hepatitis}

The varied HCV GTs, subtypes and strains showed different degree of liver damage [83, 245, 246]. Subtype 1b, which has more efficient viral replication ability and 


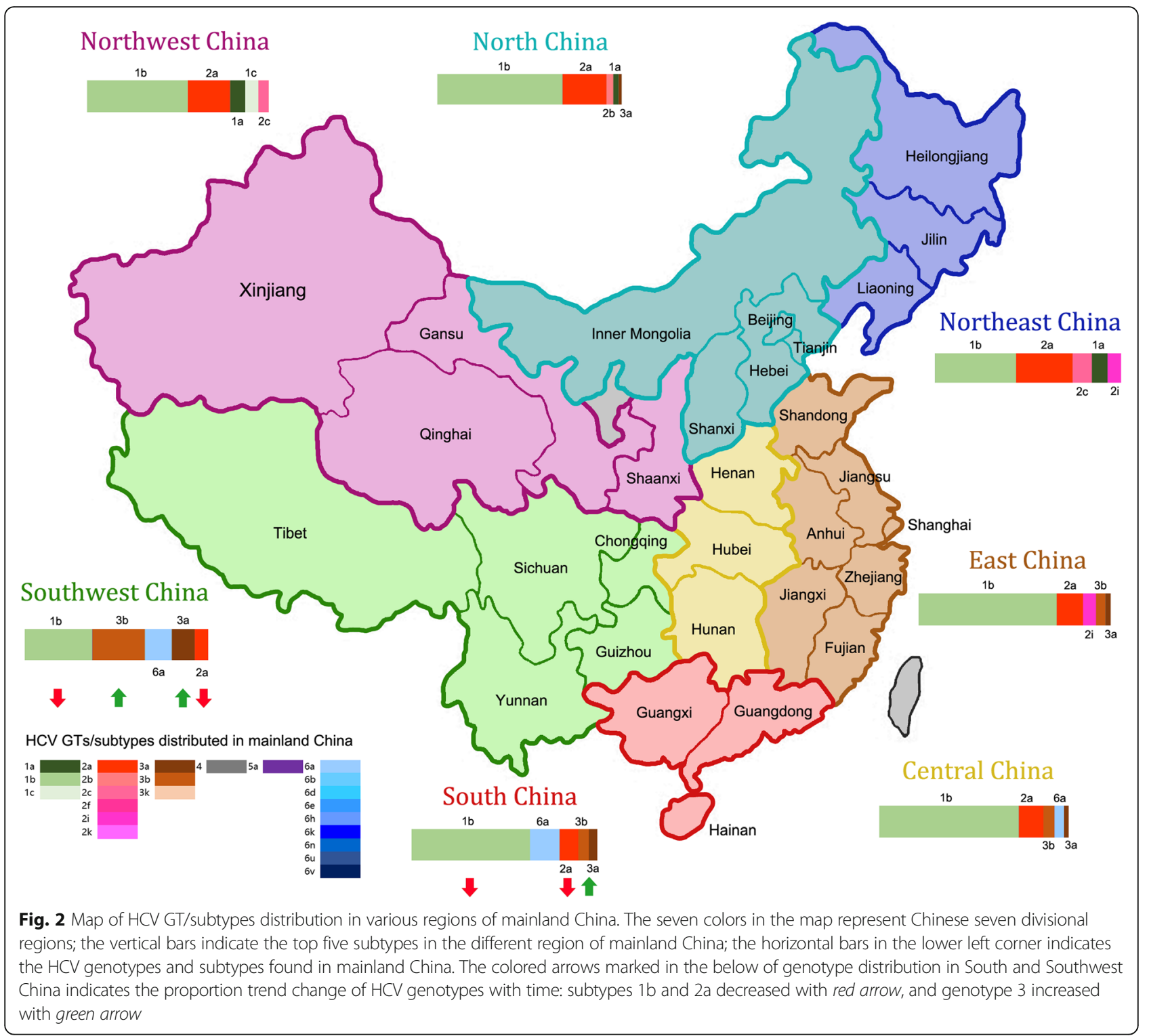

poor prognosis and possesses major proportion of severe liver disease (LD), is associated with HCV-related LC and HCC $[83,88,117,158,247]$ than non-1b subtypes. The viral genome rapid replication is higher in patients with GT 1 than that in other GTs. As a result, the consequent liver histological grading and hepatitis progress speed are considerably higher than those of GT 2 infected patients, which would lead GT 1 more incline to progress into $\mathrm{HCC}$ consistently with previous report [87]. A study found that 5 patients with LC among 94 cases were all GT 1b [50], while 1a, 2a, 2b, 3a were more common in chronic hepatitis patients without LC and liver cancer [117, 248]. Patients infected with subtype 4 were also reported to be associated with the decompensated liver complications [249], and this strong cytotoxic effect may be associated with specific proteins encoded by subtype-specific mutant genes [250, 251]. However, other research showed that no significant differences were found between $\mathrm{HCV}$ GTs and outcome of $\mathrm{HCV}$ infections [31, 96, 128, 252]. Even so, consistent results reported presently in and out of the county were found that $1 \mathrm{~b}$ account for a larger proportion in moderate and severe chronic hepatitis and LC than in acute, mild chronic hepatitis [253, 254], which may give us some suggestion that a proactive clinical management should be important for patients infected by $\mathrm{HCV} 1 \mathrm{~b}$. In addition, researches launched outside China also showed that HCV-GT 3 was associated with severe LD $[255,256]$.

Considering these conflicting and complex results above, we extracted the qualified literature $[8,41,59,65$, $83,85,87,96,97,126,128,140]$ from the screened hospitalized patients to summary the related cases in 
Table 3 Proportion change significance of HCV GT distribution with time in South and Southwest China

\begin{tabular}{|c|c|c|c|c|}
\hline Region & Subtype & Year & Proportion & $P$ \\
\hline \multicolumn{5}{|l|}{ South China } \\
\hline & \multirow[t]{3}{*}{$1 b$} & Before 2005 & $63.35 \%(159 / 251)$ & \multirow[t]{3}{*}{$<0.05$} \\
\hline & & 2005-2010 & $63.09 \%(400 / 634)$ & \\
\hline & & After 2010 & $55.00 \%(363 / 660)$ & \\
\hline & \multirow[t]{3}{*}{$2 a$} & Before 2005 & $14.34 \%(36 / 251)$ & \multirow[t]{3}{*}{$<0.05$} \\
\hline & & 2005-2010 & $8.83 \%(56 / 634)$ & \\
\hline & & After 2010 & $9.39 \%(62 / 660)$ & \\
\hline & \multirow[t]{3}{*}{3} & Before 2005 & $6.28 \%(12 / 191)$ & \multirow[t]{3}{*}{$<0.05$} \\
\hline & & 2005-2010 & $3.55 \%(45 / 1268)$ & \\
\hline & & After 2010 & $8.08 \%(91 / 1126)$ & \\
\hline \multirow[t]{9}{*}{ Southwest } & \multirow[t]{3}{*}{$1 b$} & Before 2005 & $36.99 \%(54 / 146)$ & \multirow[t]{3}{*}{$<0.05$} \\
\hline & & 2005-2010 & $18.98 \%(41 / 216)$ & \\
\hline & & After 2010 & $35.23 \%(167 / 474)$ & \\
\hline & \multirow[t]{3}{*}{$2 a$} & Before 2005 & $21.92 \%(32 / 146)$ & \multirow[t]{3}{*}{$<0.05$} \\
\hline & & 2005-2010 & $6.48 \%(14 / 216)$ & \\
\hline & & After 2010 & $3.04 \%(11 / 362)$ & \\
\hline & \multirow[t]{3}{*}{3} & Before 2005 & $11.21 \%(25 / 223)$ & \multirow[t]{3}{*}{$<0.05$} \\
\hline & & 2005-2010 & $31.71 \%(137 / 432)$ & \\
\hline & & After 2010 & 18.88\% (179/948) & \\
\hline
\end{tabular}

$P<0.05$ indicates significant difference

mainland China among different GTs based on severity of hepatitis (chronic hepatitis; cirrhosis; hepatocellular carcinoma), and performed the statistical analysis. The overall result showed significant difference $(P<0.05)$, which may indicate HCV GT is associated with severity of hepatitis. Significant difference was found between subtypes $1 \mathrm{~b}$ and $2 \mathrm{a}, 3 \mathrm{~b}$, and the significant difference was not found in the other subtypes (Table 5). The possible reason for subtype $1 \mathrm{~b}$ being more inclined to cause severe LD than subtypes $2 \mathrm{a}$ and $3 \mathrm{~b}$ may be that subtype $1 \mathrm{~b}$ has stronger pathogenicity and replication ability. In addition, the host factor should also be considered. Based on the above results, this may provide useful and instructional information for clinical treatment, and further

Table 4 Comparison of RNA levels of HCV with different subtypes

\begin{tabular}{|c|c|c|}
\hline \multirow[t]{2}{*}{ Subtypes } & \multicolumn{2}{|c|}{ HCV RNA levels (lg copies/ml) } \\
\hline & $<10^{6}$ & $\geq 10^{6}$ \\
\hline $1 b$ & & 937 \\
\hline $2 a$ & 208 & 41 \\
\hline $3 a$ & 62 & 16 \\
\hline $3 b$ & 27 & 66 \\
\hline $6 a$ & & 177 \\
\hline
\end{tabular}

Table 5 Comparison of severity of Hepatitis with different genotypes

\begin{tabular}{llll}
\hline Subtypes & \multicolumn{3}{l}{ Degree of liver disease } \\
\cline { 2 - 4 } & chronic hepatitis & liver cirrhosis & hepatocarcinoma \\
\hline $1 a^{a}$ & 8 & 1 & 1 \\
$1 b$ & 395 & 165 & 46 \\
$2 a$ & 228 & 41 & 13 \\
$3 a$ & 23 & 5 & \\
$3 b$ & 35 & 2 & \\
\hline
\end{tabular}

${ }^{\mathrm{a}}$ Fisher's exact test

(1) $1 \mathrm{a}$ and 1b, 2a, 3a, 3b: $P>0.05$ (2) 1b and 2a, 3b: $P<0.05$; $1 \mathrm{~b}$ and 3a: $P>0.05$

(3) 2a and 3a, 3b: $P>0.05$ (4) $3 \mathrm{a}$ and $3 \mathrm{~b}: P>0.05$

mechanism study may be badly needed to clarify the association between HCV GTs and severity of hepatitis.

\section{HCV GTs and antiviral treatment efficacy}

In China, the current standard-of-care (SOC) for the treatment of patients chronically infected with $\mathrm{HCV}$ is the combination therapy of PEGylated interferon alpha and ribavirin (PEG-IFN and RBV, PR); however, HCV GT is an important viral factor to predict therapeutic response and duration of treatment [257, 258]. Various genotypes of $\mathrm{HCV}$ have showed different treatment effects. Patients with GT 2 and 3 can achieve relative high SVR of $70-80 \%$, yet patients with GT 1 and 4 showed bad effect with the low SVR of $40-50 \%$ [259-262]. This may be ascribed to the different pathogenicity and replication ability of $\mathrm{HCV}$ with different GTs and the host cell factor [263, 264]. However, the mechanism still need to be clarified in the future, and some previous studies have reported that this may be associated with increased amount or mutation of E2 protein and the binding of NS5A protein to the protein kinase (PKR) $[265,266]$, a kind of antiviral protein normally induced by IFN during treatment.

With the development of new potent DAA and its combinations, the cure rate of $\mathrm{HCV}$ infection reaches $>90 \%$ in almost all HCV GTs and stages of LD [267, 268]. Especially, Epclusa, the first oral fixed-dose combination, shows high SVR for all six major HCV genotypes, and even in patients with decompensated cirrhosis, the SVR12 can achieve 94\% [269]. Actually, China has completed the clinical trials of some DAA drugs that sofosbuvir - daclatasvir or Harvoni, daclatasvir + asunaprevir, Ledipasvir/ sofosbuvir and sofosbuvir + PEG/RBV are all safe and effective in Chinese patients with chronic hepatitis C [270]. Unfortunately, this DAA combination therapy is not costeffective and for the moment, PR remains a good alternative to treat Chinese patients chronically infected with HCV with above $80 \%$ SVR which is higher than that in Europe and America [271]. 


\section{Conclusion}

To sum up, HCV GTs and subtypes showed significant geographical distribution divergence in China. Along with the increasing mobility of the population, the HCV genotype distribution changes gradually. HCV GT distribution and co-infection data from our comprehensive statistical analysis in Chinese patient population provide important diagnostic and prognostic information for more effective treatment of HCV infections. In addition, more attention should be paid to intravenous drug abusing, which may have become a new risk factor for $\mathrm{HCV}$ transmission in China. Above all, it is urgently need to launch large-scale multi-center studies to discover the associations between HCV genotypes/subtypes and some clinical and viral factors described above. All those information are important to implement personalized and precision medicine in China for $\mathrm{HCV}$ infections and the relative hepatitis.

\section{Abbreviations}

HCV: Hepatitis C virus; ETVR: End of treatment virological response; GTs: Genotypes; HCC: Hepatocellular carcinoma; HDs: Hemodialysis patients; IDUs: Intravenous drug users; LC: Liver cirrhosis; LD: Sever liver disease; LiPA: Line probe hybridization method; PCR-RDB: Polymerase chain reactionreverse dot blot; PR: PEGylated interferon alpha and ribavirin; PTHC: Posttransfusion hepatitis; RFLP: Restriction fragment length polymorphism; SOC: Standard-of-care

\section{Acknowledgements}

Not applicable.

\section{Funding}

This study was supported by Natural Science Foundation of China (81572089).

\section{Availability of data and materials}

Please contact author for data requests.

\section{Authors' contributions}

YZ carried out the study concept, data collection, analysis and drafting the manuscript. $\mathrm{MH}$ has full access to all of the data in the study and takes responsibility for the integrity of the data and the accuracy of the data analysis. LM C gave an improved suggestion about the whole article. All authors read and approved the final manuscript.

\section{Competing interests}

The authors declare that they have no competing interests.

\section{Consent for publication}

Not applicable.

\section{Ethics approval and consent to participate}

Not applicable.

\section{Author details}

${ }^{1}$ Institute of Blood Transfusion, Peking Union Medical College, Chinese Academy of Medical Sciences, Chengdu 610052, China. ${ }^{2}$ Sichuan Blood Safety and Blood Substitute, International Science and Technology Cooperation Base, Chengdu 610052, China. ${ }^{3}$ Toronto General Research Institute, University of Toronto, Toronto, ON, Canada.
Received: 5 September 2016 Accepted: 15 February 2017

Published online: 23 February 2017

\section{References}

1. Cai LN, Zhu SW, Zhou C, Wang YB, Jiang NZ, Chen H, Tang XY, Wang JH, Chen $\mathrm{X}, \mathrm{Hu}$ WJ, et al. Infection status of HBV, HCV and HIV in voluntary blood donors of Chinese Nanjing area during 2010-2013. Zhongguo Shi Yan Xue Ye Xue Za Zhi. 2014;22:1089-93.

2. $C P, G A, J P, L F, Y$ : Estimated Global Prevalence of Hepatitis C Virus Infection. [J] Annual Meeting 2004.

3. Thomas DL. Global control of hepatitis C: where challenge meets opportunity. Nat Med. 2013;19:850-8.

4. Bennett $H$, Waser N, Johnston K, Kao JH, Lim YS, Duan ZP, Lee YJ, Wei L, Chen $C$, Sievert W, et al. A review of the burden of hepatitis $C$ virus infection in China, Japan, South Korea and Taiwan. Hepatol Int. 2015;9:378-90.

5. Gower E, Estes C, Blach S, Razavi-Shearer K, Razavi H. Global epidemiology and genotype distribution of the hepatitis C virus infection. J Hepatol. 2014; 61:S45-57.

6. Ye Y, Yan YS, Chen G, Yan PP, Zheng WX, Deng YQ, Yang XH, Wu SL, Zhang ZS. Molecular epidemiology of hepatitis $C$ virus among different groups of people in the province of Fujian, China. Arch Virol. 2013;158:611-8.

7. Peng J, Lu Y, Liu W, Zhu Y, Yan X, Xu J, Wang X, Wang Y, Liu W, Sun Z. Genotype distribution and molecular epidemiology of hepatitis $C$ virus in hubei, Central China. PLoS One. 2015:10:e0137059.

8. Zhang Lx, An Y, Zhang Xg, Liu LW, Jinhong Y: Genotypre distribution of chronic HCV infectors in Shandong. Pathogen Biol 2011:567-570

9. Moradpour D, Penin F, Rice CM. Replication of hepatitis C virus. Nat Rev Microbiol. 2007;5:453-63.

10. Reed KE, Rice CM. Overview of hepatitis C virus genome structure, polyprotein processing, and protein properties. Curr Top Microbiol Immunol. 2000;242:55-84.

11. Simmonds P, Holmes EC, Cha TA, Chan SW, McOmish F, Irvine B, Beall E, Yap PL, Kolberg J, Urdea MS. Classification of hepatitis C virus into six major genotypes and a series of subtypes by phylogenetic analysis of the NS-5 region. J Gen Virol. 1993;74(Pt 11):2391-9.

12. Gu L, Tong W, Yuan M, Lu T, Li C, Lu L. An increased diversity of HCV isolates were characterized among 393 patients with liver disease in China representing six genotypes, 12 subtypes, and two novel genotype 6 variants. J Clin Virol. 2013:57:311-7

13. Guie' $X$, Shaojing. W: Research on HCV genotype among HCV infectors in Guangzhou. J Trop Med 2014:589-594 + 598

14. Simmonds P, Bukh J, Combet C, Deleage G, Enomoto N, Feinstone S, Halfon $P$, Inchauspe $G$, Kuiken C, Maertens $G$, et al. Consensus proposals for a unified system of nomenclature of hepatitis $C$ virus genotypes. Hepatology. 2005:42:962-73.

15. An Y, Wu T, Wang M, Lu L, Li C, Zhou Y, Fu Y, Chen G. Conservation in China of a novel group of HCV variants dating to six centuries ago. Virology. 2014; 464-465:21-5

16. Gu B, Huang H. HCV genotypes of Chenzhou and the correlation analysis of viral load. Chin J Clin Hepatol. 2013;29:832-834.

17. Zhou $Y$, Yin F. Research on association between HCV viral load, genotype and antiviral effect. Practical journal of liver disease. 2011;14:340-343.

18. Zhou Q, Li Y. HCV genotyping in Wuhan, and analysis of liver funcion in chronic patients and blood index. Int J Lab Med. 2013;34:1693-1695.

19. Lu E, Tong Y. Analysis of HCV genotype in 273 HCV infectors. Xiangyang vocational and technical college. 2015;14:27-29.

20. Song S, Gui W. HCV genotype analysis of 169 cases in Wuhan. Practical journal of clinical medicine. 2015;19:36-38.

21. Huang Q, Cao J. HCV genotype detection with PCR-RDB in Wuhan. Chinese Journal of Nosocomiology. 2011:21:2674-2676.

22. Wang J, Yuan W. Oligonucleotide array chip detection of hepatitis c virus ( $\mathrm{HCV}$ genotype and clinical application. Chinese Journal of Laboratory Medicine. 2005;28:1248-1252.

23. Bao A, Li Y, Tong Y, Zheng H, Wu W. HCV genotyping of chronic patients and therapeutic effect evaluation in Hubei. J Mod Lab. 2013;28:13-6.

24. Wu Z, Li Y. HCV genotyping results of 254 cases in Wuhan. Journal of Modern Laboratory Medicine. 2014;29:124-126.

25. Li W, Zeng Y. HCV genotype distribution research among chronic HCV infectors in Henan. The diagnosis and treatment of practical magazine. 2015;29:538-539.

26. Cheng S, Zhang B, Zhao L, Guo R, Xu Y, Li W, Fang J. HCV genotyping for HCV carrier donors and HCV patients. Chinese Journal of Misdiagnostics. 2003;3:1330-1331. 
27. Cui W, Sun G, Xiao Z, Liu J, Xing W, Wang Z: HCV genotype analysis of 121 HCV patients in Henan. Chin J Health Lab Technol. 2013;23:2220-2223.

28. Liu X, Wang D. HCV genotyping in Henan. World Chin J Dig. 2000;8:922-923.

29. Cui W, Xue X, Liu C, Sun G, Liu J, Fan P, Tai S, Sun D, Xing W. HCV infection status and genotyping analysis in Henan 2012. Chin J Prev Med. 2013;47:518-22.

30. Huo Y, Xu D. HCV genotyping among HCV patientsin Xi'an and Zhengzhou. J Fourth Mil Med Univ. 2002;23:749-751.

31. Shi C, Huang Y. HCV genotype research in Qingdao. Acta Academiae Medicinae Qingdao Universitatis. 2014;50:230-232.

32. $\mathrm{Xu} \mathrm{W,} \mathrm{Liu} \mathrm{L.} \mathrm{Hepatitis} \mathrm{c}$ virus (HCV) genotypes in shandong district and the analysis of related factors. Journal of Shandong University. 2010:140-141 + 145.

33. Liu Y, Tian W. HCV genotyping research among 153 Han Chinese people in Shandong. Laboratory Medicine and Clinic. 2014;11:2649-2650.

34. Zhang L, Wang L, Xu W. Hepatitis c virus genotype and serum credits type research in Shandong. Chin J Clin Hepatol. 2005;21:215-216.

35. Zhang G, Pu S, Yu X. Research on HCV genotyping in Yantai, Shandong. The Experimental and Clinical Virology Journal. 2012;26:259-262.

36. Yu X, Sun S, Jiang Y: HCVgenptyping distribution ans its clinical significance in Yantai, Sandong. Medical Laboratory Science and Clinics. 2013;24:6-9.

37. Zhao W, Liu W. A preliminary study on HCV genotyping using Hepatitis diagnostic chip. Chinese Medical Journal. 2002;82:28-32.

38. Zhang Y, Sun N, Huang Z. Research on HCV genotyping in Jiangsu. Jiangsu Medical Journal. 2004;30:463-464.

39. Lu R, Huang L. Molecular epidemiology of HCV in Nantong, Jiangsu. Journal of Nantong University. 2015;35:30-33.

40. Xu K: hepatitis c virus genotype distribution and coated area variation study in Yixing, Jiangsu Master. Nanjing Medical University. 2006.

41. Shen L, Gu X. HCV genotype in Nanjing, HCV RNA and clinical prognosis. Jiangsu Medical Journal. 2007;33:1050-1051.

42. Cao J, Wang Y, Shi Y, Zhang D, Zhang q, Chen L, Mao L, Wang H. HCV genotyping for chronic patients in Nantong. Chinese medical journal of transportation. 2005;19:75-76.

43. Miu H, Jiang L. HCV genotype distribution in the areas of southern jiangsu and its relationship with the percentage of NK cells abnormal. Clinical Medical Engineering. 2010;17:18-19.

44. Zang X, Yao LG, Jianwen. HCV - RNA quantitative detection and genotyping in Changwu. China's health care nutrition ten-day periodical. 2013;23:6868-6869.

45. Chen L, Wang YS, yingjuan, Cao J, Zhang D, Mao H, Zhao J, Mao L, Wang H, The clinical application of HCV genotyping DNA microarray and significance. Journal of Modern Laboratory. 2005;20:8-10.

46. Yang X, Wu G. HCV genotyping and helper T cells factor expression in peripheral blood of Wuxi, Jiangsu. J Mod Lab Med. 2012;27:73-5.

47. Wu X, Chen L. HCV genotype distribution investigation of xuzhou and the surrounding area. Disabled Chinese Medicine. 2014;22:34-35.

48. Ding W, Shao J, Xu K, Pan J, Tan S, Deng X, Yu R, Hu X, Zhang Y. Hepatitis C virus genotypes in Yixing area and variation of analysis. China Pub Health. 2005;21:1193-4

49. Jiang S, Wang J: HCV epidemiological and clinical curative effect in northern Anhui Province. Chin J Clin Hepatol 2012;28:937-940.

50. Zhou W, Qian F. HCV genotype distribution in Huzhou, Zhejiang. Surveillance of disease. 2012;27:25-27.

51. Ding S, Zhou W, Hu A, Liang X, Weng P. Hepatitis C virus genotype points detection in ningbo area. Chin J Health Lab Technol. 2011;21:2453-2454.

52. Xiong T, Hu A: HCV genotyping and viral load and the relevant analysis of HCV viral load and disease progression. Disease surveillance. 2015;30:19-22.

53. Qian F, Zhou W. Application research od gene chip on HCV genotype among chronic HCV infectors. China Preventive Medicine. 2012;13:530-532.

54. Xiong T, Hu A. Reserch on HCV genotyping The eastern region of zhejiang province. Chinese Journal of Nosocomiology. 2015;25:5139-5141.

55. Wang M, Xu B. Phylogenetic tree analysis of HCV genotypingin chronic hepatitis c patients. Journal of Medical Research. 2012;41:76-78.

56. Liu J, Huang Y. Hepatitis c genotype distribution characteristics and the epidemical analysis. International Journal of Laboratory Medicine. 2010;31: 1347-1348.

57. Gui $Y$, Zheng $H$. Hepatitis c virus genotyping of jiujiang area. Experimental and Laboratory Medicine. 2010;28:480-514.

58. Xie N, Zhu X. Micro board nucleic acid hybridization technology observation on HCV genotyping in Jiangxi area. Acta Acad Med. Jiangxi, Acta Academiae. 2003:49-50+55.

59. Huang G, Chen C. PCR-RDB detection for Hepatitis c virus. The Journal of Practical Medicine. 2006;22:1688-1690.
60. Su H, Wu X. HCV genotype distribution in Anhui. Chinese Journal of Epidemiology. 1997;18:14-16.

61. Chen X: Molecular epidemiology research on HCV infection in some natural village of Fujian Province. Master. Fujian Medical University. 2009.

62. Zhang J, Yin Y, Xie Y. HCV genotyping based on NS5B gene region. Chinese journal of anti-infective chemotherapy. 2003;3:287-290.

63. Mao H, Gu S. Establish a DNA chip technology to detect hepatitis c virus genotype and its preliminary application. The experimental and clinical virology journal. 2003;17:77-79.

64. Li Y, Chenjianjie. HCV genotype distribution research among 71 chronic patients in Shanghai. Combine traditional Chinese and western medicine liver disease. 2006:360-361 + 365 .

65. Jiang W, Gu S. Hepatitis c virus genotyping research in Shanghai. Chin J Liver Dis. 1999;7:29-30.

66. Wu H, Lu Y: HCV genotyping and risk factor analysis among HCV infectors in Pudong, Shanghai. China Preventive Medicine. 2012;13:839-843.

67. Hu D, Zhao W. HCV genotyping for 215 cases in Nanjing and Guangdong and the association with transmission routs. Jiangsu Medical Journal. 2014; 40:597-598.

68. Rong $X$, Zheng Y. HCV genotyping comparation between clinical patients and donors in Guangdong. Chinese Journal of Blood Transfusion. 2014;27:593-596.

69. Huang Z, Ke C. HCV genotype classification study among HCV infectorsWith 140 cases of test analysis. New medicine. 2012:109-111 + 141.

70. Yuan X, Chen W, Wei S. Real-time fluorescent PCR technology in the application of hepatitis c virus genotype. Guangdong Medical Journal. 2011; 32:582-584.

71. Wei J, Zhang T. HCV gentype detection using PCR-RDB in Guangdong. J South Med Univ 2010:2270-2272 + 2276 .

72. Huang H, Zhou Y. Joint analysis of HCV species and highly conserved sequence to determine HCv genotype in Guangdong. Guangdong Medical Journal. 2010;31:825-828.

73. Tang W, Yang Y. HCV genotyping detection among HCV infectors in Guangdong. Practical journal of clinical medicine. 2008;15:1373-1376.

74. Hu B, Zhang X. HCV genotyping research in HCV infectors in Guangdong. Journal of Tropical Medicine. 2006:1071-1072 + 1127

75. Yang G, Chen S, Cui J. Establishment of Hepatitis c virus reverse dot hybridization genotyping method and the initial application. Chinese Journal of Epidemiology. 2005;26:440-443.

76. An Y, Yang S, Yao J. Genotyping of HCV infectors and the association woth clinics in Guangdong. Acad J SUMS. 1999;20:74-77.

77. Tang W, Su M. HCV genotyping distribution and epidemiological characteristics in Guangxi. WCJD. 2014;22:1300-1306.

78. Tang W. HCV genotyping and its clinical significance in Guangxi. Master. Guangxi Medical University. 2014.

79. Zhou J, Xiao J. HCV genotyping reaserch in Haikou. Modern Preventive Medicine 2012:4507-4508 + 4510 .

80. Cai Q, Hong C, Zhang X, Zhao Z, Gao Z. Comparation of HCV genotyping method based on core gene and NS5B and line probe assay for chronic patients in Guangdong. Chin J Infect Dis. 2012;30:542-7.

81. Li Y, Yang Y: HCV genotyping research among chronic patients in Zhuhai region. Chin J Health Lab Technol 2009;19:1071-1073.

82. Liu L, Zhang R. China southern and southwestern genotype distribution characteristics of HCV infection. China Journal of Modern Medicine. 2007;17: 2337-2340.

83. Zhang $Y$, Zhao D, Zhang $Y$. Xingtai area HCV genotype distribution and its relationship with disease progression and sustained virological response. Chin J Clin Hepatol. 2015;31:1845-1848.

84. Yan Y, Li Z. HCV - RNA quantitative detection and genotyping of research among HCV infectors in Beijing. Medicine theory and practice. 2007;20:756-757.

85. Liu Z, Wei H. HCV genotyping among HCV infectors in Beijing. Chin J Epidemiology. 2005;26:148-9.

86. Zhang M, Han T, Xiao S. Transmission routs ananlysis among chronic hepatitis c infectors in Tianjin. Shandong Medical Journal. 2013;53:1-3.

87. Fan G, Wen W, Han J, Hu X, Chen T, Cao J. HCV RNA detection and genotype research in Mongolian people. Practical Preventive Medicine. 2012:19:1867-1869.

88. Wang Y, Zhu Y. HCv genotyping and its clinical significnace in Taiyuan. Practical journal of liver disease. 2010;13:109-111.

89. Wu L, Liu Y. Research on HCV genotype among different group people in Shanxi. The Chinese journal of microbiology and immunology. 2001; 21:14-17 
90. Zhou Z, Xu H. HCV genotype distribution and its clinical significance in Chongqing. Journal of Chongqing Medical University. 2015;40:383-387.

91. Liang Y, Yang X. HCV genotype in HCV patients in Guizhou and correlation studies associated with the peripheral helper $T$ cell factor expression. Guizhou Medical Journal. 2015;39:301-303.

92. Liang Y. HCV genotype in HCV patients and the correlation ananlysis associsted with serum viral load and Blood biochemical cytology index. Guizhou Medical Journal. 2015;39:14-17.

93. Li Y, Bi S. Correlation analysis of hepatitis c virus genotype, viral load and peripheral blood T lymphocyte subgroup in HCV patients of Kunming. The Chinese journal of liver disease. 2015;23:142-144.

94. Yang X, Yue D. L, Li Y. HCV genotyping status in Guizhou. Journal of Guiyang Medical College. 2014;39:486-489.

95. Li Z, Gao Y. HCV genotyping research based on NS5B region. International Journal of Laboratory Medicine. 2011;32:550-552

96. Lei H, Dai J. HCV genotype and its clinical significance among HCV patients in Kunming. Hepatology. 2011;16:48-49.

97. Song H, Yi X. The HCV infection status in Tibet Tibetan crowd and HCV genotype analysis. Gastroenterology and liver disease. 1997;6:315-317.

98. Gonza Yuzhen GJ. The preliminary study of hepatitis c virus (HCV) genotypes among Tibet population. Tibetan medicine journal. 1996:9-10 +65.

99. Zhang F, Wang X, Wang Y. HCV subtype distribution state in Chongqing J Fourth Mil Med Univ. 2005;26:1253-1256.

100. Liu B, Wang Y. HCV genotyping research on 69 cases in Chongqing. Chongqing Medical Journal. 2002;31:174-175.

101. Ding L, Zhong H, Lu X, Zhou J, Liu X, Ying B. HCV genotype distribution and relevance to the antiviral effect inSichuan people. Journal of Sichuan University. 2015;46:573-577.

102. Liu X. Study on association between HCV viral load and genotype among single and HIV/HCV infectors. Master. Fudan University. 2011.

103. Li B, Zhang T. Genotype distribution of HCV carriers and clinical significance among HCV patients. Shaanxi Medical Journal. 2015:44:1375-1377.

104. Wang J. Different genotype distribution characteristics in southern Gansu. Laboratory Medicine and Clinic. 2014;11:2364-2365.

105. Li M, Tao G. HCV genotype characteristics in Baiyin. The Western Medicine 2014;27:63-65

106. Yang W, Xu H. Genotypes characteristics HCV infection in four different ethnicity of Gansu. Journal of gansu college of traditional Chinese medicine. 2013;30:27-30

107. Yang J, Li Z, Tian S. Relationship between the autoantibodies dynamic change and the HCV - RNA genes. International Journal of Laboratory Medicine. 2012;33:2960-2962.

108. Xu H, Yang W. Research on HCV genotyping Dongxiang Autonomous County of Gansu. Molecular diagnosis and therapy. 2012;4:111-114.

109. $\mathrm{Xu} \mathrm{H}$, Ju J. HCV genotyping research in a region. International Journal of Laboratory Medicine. 2012;33:683-684.

110. Liang C. HCV genotyping among chronic HCV ininfectors and antiviral therapeutic effect analysis in Wuwei. Gansu Medical Journal. 2012;31: 900-902.

111. Zhang W, Liu L, Du S. HCV genotype distribution characteristics in Lanzhou, China. Chin J Clin Hepatol. 2010:290-291 + 294

112. Chen Q, Guo Z, Xiao P, Yang Y, Xiong Y, Yue W. HCV serotyping and genotyping and study on the relationship with the interferon antibody in Gansu. International Journal of Laboratory. 2006;27:612-614.

113. Peng C, Mao X. HCV genotyping annalysis of the Han chinese people in Gansu. Chin J Clin Hepatol. 2013;29:828-831.

114. Xu H, Yang W. Research on HCV genotyping in Tibetan of Gansu. International Journal of Laboratory Medicine. 2012:2081-2082 + 2084.

115. Li Q, Han R, Wang X. Hepatitis c genotyping situation analysis in Wuwei area. The Chinese community physicians. 2011;13:319.

116. Liu T, Chen Z. HCV genotyping research on Uighur and han Chinese people in Xinjiang. Chinese Journal of Nosocomiology. 2015;25:4122-4124.

117. Chen Z, Liu J, Meng C, Zhang Z, Zhang C. HCV genotyping sutdy among han, uygur, kazak patients in Xinjiang. J Xinjiang Med Univ. 2015:855-857+861.

118. Xu Y, Qiu F. HCV genotyping analysis among uighurs in Xinjiang. The Experimental and Clinical Virology Journal. 2014;28:265-267.

119. Huang Y, Han F. Epidemiological characteristics and analysis of $110 \mathrm{HCV}$ infectors. Chin J Clin Hepatol. 2014;30:505-507.

120. Abdulhalili. H, Shi G. HCV genotyping ananlysis od 118 cases in Xinjiang. The Chinese journal of liver disease. 2011;19:127-128.
121. Zang Y, Xie Y, Xie C. Distribution state in Anshan central hospital. Journal of Dalian Medical University. 2015:358-360 + 366

122. Bi M, Wang X, Wang W, Chen L, Yan B, Yang B. HCV genotype and subtype distribution distribution characteristics and clinical sgnificance in Heilongjiang. Chinese journal of medical frontier. 2014;6:30-32.

123. Bai S. HCV genotyping of patients in Shenyang. China Practical Medical. 2009;4:54-55

124. Sun L, Liu W. Research on HCV serum type and genetic type. J Clin Lab Sci. 2007:25:271-272.

125. Xu C, Zhang M. HCV genotyping ananlysis of 650 chronic cases in Shenyang. The Chinese journal of liver disease. 2012;20:547-549.

126. Li X, Ma Y, Yang G. In: HCV genotyping in Jilin and its clinical significance. China Practical Medical. 2011;6:33-34

127. Xie Y, Xie C. Hepatitis C virus subtype distribution in Dalian. Chin J Hepatol. 2009;17:872-3.

128. Xie F, Shi Q, Wang J. HCV genotyping and its correlation with liver disease in Changchun. Chinese Journal of Biologicals. 2009:35-37

129. Xu G. Clinical research on HCV genotyping in Jilin. Master. Jilin University. 2008.

130. Su X, Niu J. HCV genotyping investugation in Jilin. Chinese journal of public health 1997;16:348.

131. He P, Chen C. HCV genotyping research. Journal of Medical Forum. 2010;31: $10-11$.

132. Yan X, Wu W, Wei L. HCV genotyping research on 90 cases. Acta Academiae Medicinae Xuzhou. 1997;17:14-15.

133. Chang J, Zhang Y, Wang J, Meng Y, Wang M. HCV genotyping for chronic HCV infectors and research on relationship with HCV RNA leval. Journal of Clinical Hepatology. 2012;15:321-323.

134. Shen $L$, Zhao W. Comparison of HCV distribution between donors and nondonors in Jiangsu. Chinese Journal of Nosocomiology. 2011;21:861-863.

135. Fang $Y$, Dai M, Zhang $Y$, Yan X. Hepatitis c virus genotyping research in xuzhou region. The experimental and clinical infection magazine 2014;8:317-320.

136. Zhang $H$, Zhang $X$, Li H. Hepatitis c virus genotyping and HCV RNA correlation studies among chronic HCV infectors. Laboratory Medicine and Clinic. 2014;11:3395-3397.

137. Tan G, Sun M. Hepatitis C virus genotype distribution characteristics in HCV patients of Nanjing. Clinical Focus. 2015;30:393-396.

138. Wang j, Zhou Z. Change analysis of HCV genotype in Nanjing 2007-2014. Medical Journal of Communications. 2014:666-668 + 670.

139. Yi D, Yu S. HCV genotyping distribution among HCV infectors in Jiangxi. Acta Acad Med Jiangxi. 2000:39-40.

140. Zhu S, Chen H. HCV genotyping and discussion about clinical relationship in Heilongjiang. Chinese Journal of Epidemiology. 2000;44.

141. Zhang T, Zhang S, Gao P. HCV genotyping in Lanzhou region. China Public Health. 2000;16:166.

142. Chen Z, Xie N, Zhang Z, Meng C, Gu T, Zhao J, Zhnag C. HCV genotyping study among han, uygur in Xinjiang. Chongqing Medical Journal. 2016:14-16+18.

143. Ku Q, Yu G: The association between hepatitis c gene subtype and sugar, lipid metabolism and liver damage in Qinghai. Journal of Qinghai Medical College. 2014;35:202-205.

144. Zhang $Y$, Sun H. Detecting HCV genotypes in two cities of Xinjiang using HCV NS-5 region. Xinjiang medical journals. 1998;21:40-43.

145. Nuen ZNJZ. HCV genotyping and its clinical significance in Inner Mongolia and Mongolia. Inner Mongolia Medical College. 2007.

146. Li Z, Jiang Y, Li H. Hepatitis C genotype distribution research on $82 \mathrm{HCV}$ infectors in Urumchi. J Xinjiang Med Univ. 2010:33:542-544.

147. Liu X, Feng H. Molecular epidemiological investigation on HCV and its clinical significance in Linyi City. Journal of Shandong Medical College. 2013;35:11-14.

148. Hu J, Zhang M. HCV genotype analysis among anti-HCV positive donors in Xuzhou. Journal of Modern Laboratory Medicine. 2014;29:152-153.

149. Zhu S, Shi L. HCV genotyping research among Zhejiang port entry-exit personnel. Chinese Journal of Nosocomiology. 2013;23:3840-3842.

150. Chen Y, Sun C, Wang S. Analysis of HCV genotyping among HCV infectors in Zhejiang. Journal of Laboratory Medicine and Clinic. 2015;12:43-45.

151. Niu J, Xu R. HCV genotype research in Hebei. VIROLOGICA SINICA. 2003;18:611-3.

152. Jin H, Lin B, Liu S. Hepatitis C virus (HCV) genotypes and the correlation of clinical research in Tianjin. Journal of Tianjin Medical University. 2014:286-288 + 292.

153. Tan B, Li J. Epidemiological investigation of hepatitis c virus (HCV) infection and genotyping research in Tongren. Chinese Journal of Nosocomiology. 2015;25:4125-4127.

154. Jian W, Zhang F. HCV RNA genotyping in Harbin area. Practical journal of liver disease. 1997;2:225-226. 
155. Deng L, Gui X, Gao S, Xiong Y, Yang R, Chi M. HCV genotyping among HIV infected population transmitted by blood transfusion in some region of Hubei. Chin J Gen Pract. 2012;11:441-3.

156. Zheng J, Liu Y. Research on HCV genotyping among IDUs in Jiangsu. Journal of Medical Postgraduates. 2011;24:816-820

157. Cui L. Research on HCV genotype distribution among population being monitored with HIV/AIDS in Anhui. Master. Anhui Medical University. 2015

158. Lin R, Wag B. HCV genotype distribution characteristics ans its clinical significance in Wenzhou. China Medical Herald. 2014;11:58-60.

159. Li J, Xie N. HCV genotypes research in patients infected with HIV/HCV using chip technology. Experimental and Laboratory Medicine. 2014;32:395-397.

160. Pu X, Hang S. HCV genotyping and clinical ananlysis in Changzhou. Journal of Radioimmunology. 2012;25:663-665.

161. Liu J, Huang Y. HCV genotype ananlysis of 41 chronic HCV IDUs. Laboratory Medicine and Clinic. 2011;23:2914-2915.

162. Zheng JF, Liu Y. A research on HCV genotype distribution among IDU in Jiangsu. Journal of Medical Postgraduates. 2011;24:816-820.

163. Yang $Y$. The full-length seguence ananlysis of HIV-1main strain and HCV genotyping among HIV/HCV coinfectors in Shanghai. Master. Second Military Medical University. 2009.

164. Wen J, Duan Z. Research on HCV genotype among 62 cases in Wenzhou. Journal of clinical hematology. 2009:70-72

165. Li X. HCV genotype research in southern anhui. Master. Anhui Medical University. 2009

166. Gong J, Yang J. Common HCV genotype classification study among IDUs in Nanjing. Southeast of the national defense medical. 2009;11:199-201.

167. Liao Q, Xu R. The association between HCV genotype and viral load among unpaid blood donors positive to anti-HCV in Guangzhou. Chin J Immunol. 2012;28:242-245.

168. Wang M, Xu R. HCVE1 and NS5B gene sequencing and genotyping among unpaid donors in Guangdong. Chinese Journal of Blood Transfusion. 2011; 24:201-205.

169. Ye H, Xu R, Wang M. HCV genotyping study among unpaid donors in Guangzhou. J South Med Univ. 2010;30:2655-2657.

170. Ge X, Wang S. HCV infection among IDUs in Guangxi and its molecular biology research. Guangxi Journal of Preventive Medicine. 1996:2:1-7.

171. Kuang Y, Huang X. HCV genotypes in 209 intravenous drug users positive to HIV-1. South China preventive medicine. 2015;41:124-131.

172. Rong $X, X u$ R. Epidemiological characteristics of hepatitis $\mathrm{c}$ virus (HCV) among unpaid donors in Guangzhou, 2009-2011. Chinese Journal of Viral Diseases. 2013;3:362-366.

173. Zhong Q, Liu Z. HCV genotyping study among IDUs in Guangzhou. Chin J Misdiagnostics. 2012;12:3796-8.

174. Liao Q. Molecular epidemiology research on HCV infection among volunteers in Guangzhou. Master. Chongqing Medical University. 2012.

175. Huang T, Rong X. HCV genotyping and virus drops degree correlation studies among volunteers in Guangdong. Chinese Journal of Blood Transfusion. 2012;25:1063-1065.

176. Wang M, Xu R, Rong X. HCV sequencing and genotyping based on E1 and NS5B among voluntary blood donors in Guangzhou. Chinese Journal of Blood Transfusion. 2011:24:201-205.

177. Fu Y, Wang Y, Xia W, Pybus OG, Qin W, Lu L, Nelson K. New trends of HCV infection in China revealed by genetic analysis of viral sequences determined from first-time volunteer blood donors. J Viral Hepat. 2011;18:42-52.

178. Wang Y. Molecular epidemiological studies among unpaid blood donors in Guangzhou and new subtype identification of 6 v. Sun Yat-sen University. 2009.

179. Wang M, Zhou Y, Chen F: Determination of the nucleotide sequence and genotyping among unpaid donors in Yunnan and Shanxi. Chinese Journalof Blood Transfusion. 2009;22:875-879.

180. Huang C, Zhou J. HCV subtype investigation in a illegal blood village in Hebei. Exp Clin Virol J. 2009:23:8-10

181. Huang C. Serological and molecular epidemiological investigation on HCV in some 'blood donation village' in Hebei. Master. Hebei Medical University. 2009

182. Wu L, Liu Y: HCV genotyping ans sequence ananlysis among IDUs in Shanxi. China Preventive Medicine 2002;3:37-40.

183. Ding X, Gu H, Zhong ZH, Zilong X, Tran HT, Iwaki Y, Li TC, Sata T, Abe K. Molecular epidemiology of hepatitis viruses and genotypic distribution of hepatitis B and C viruses in Harbin, China. Jpn J Infect Dis. 2003;56:19-22.
184. Jia G, Liu Y. HCV genotyping among unpaid blood donation population in Xianyang. Clinical blood transfusion and inspection. 2015;17:331-334.

185. Abla A, Abdurishid G, Mamt D, Rouzi A, Ca M, Adical P, Ni MJ, Li M, TaHr: HIV infected Kuqa Uighur population coinfected with HCV and the determination of the subtype. For disease control and prevention. 2015;30:5-8.

186. Kou J, Lei C. HCV genotypes investigation among paid donors in Dingxi, Gansu. Gansu Medicine. 2013:32:377-379.

187. Xu R, Fang J. HCV molecular epidemiology research among unpaid donors in northwest. Chinese Journal of Blood Transfusion. 2009;22:880-883.

188. Zhang Z. HCV molecular epidemiology research on IDUs in Yunnan. Master. Peking Union Medical College. 2014.

189. Zhang SQ, Wang YL, Li XF. Chracteristics of HCV genotyping and analysis of the spreading trend in patient cofected with HIV and HCV. International Journal of Laboratory Medicine. 2014;35:920-922.

190. Wang J, Wang J. HCV genotyping among HIV infectors in Dali, Yunnan. Journal of Pathogen Biology. 2014:9:131-134.

191. Zhang Z, Yao Y, Wu W, Feng R, Wu Z, Cun W, Dong S. Hepatitis C virus genotype diversity among intravenous drug users in Yunnan Province, Southwestern China. PLoS One. 2013;8:e82598.

192. Su L, Qin G. Molecular research on HCV genotype among HIV/HCV coinfection infectors in Liangshan. Journal of Preventive Medicine Information. 2013;29:548-552.

193. Wang Z, Yuan X. Hepatitis c virus genotype distribution and epidemiological characteristics in Liuta rural area, Puyang City, Henan. Disease surveillance. 2013:28:560-563.

194. Tao J, Liu Y. HCV genotyping research among IDUs in Guizhou. Chinese Journal of Viral Diseases. 2012:2:117-122.

195. Pu D, Wang Y. Hepatitis c virus genotype characteristics among HIV/HCV infectors in Kunming. China Tropical Medicine. 2011;11:662-664.

196. Zhao S, Li B. Epidemiology investigation of HCV among unpaid donors in Chongqing. Chongqing Medical Journal. 2006:964-966 + 968.

197. Fang Y, Chen S, Wang Y, Li C. Investigation on infection status of IDUs in Chongqing. Chin J Drug Depend. 2001;10:220-222.

198. Chen M, Ma Y, Luo H, Chen H, Lu R, Dai J, Song L, Yang C, Mei J. Analysis of HCV genotyping among IDU in Kunming. Chin J Epidemiol. 2015;36:994-997.

199. Wang Y, Yu Q. HCvgenotyping among HCV patients in Qingdao. Preventive Medicine Tribune. 1998:4:331-331.

200. Zhao SM, Jiang TL, Li RQ, Gao FX, Lu L, Zheng HQ, Hu J, Fan YH, Li B, Xiao $\mathrm{RQ}$, Yury K. HCV infection in voluntary donors and its influence on recruitment of donors in Chongqing area. Zhongguo Shi Yan Xue Ye Xue Za Zhi. 2008;16:676-80.

201. Zhao J. HIV/HCV infection among high-risk population in Central and western China and preliminary analysis of HCV subtypes. Master. Chinese Center for Disease Control and Prevention. 2009.

202. Zeng J, Yang g, Chen S, Cui J. HCV genotyping in Foshan and the association with HCV voral load study. Chin J Health Lab Technol. 2013:3564-3565 + 3573.

203. Zhang J, Yang L. HCV genotyping and is clinical significance in Shijiazhuang. Medical frontier. 2012:2:178-179.

204. Nolte FS. Hepatitis C virus genotyping: clinical implications and methods. Mol Diagn. 2001;6:265-77.

205. Pawlotsky JM. Use and interpretation of virological tests for hepatitis C. Hepatology. 2002;36:565-73.

206. Murphy DG, Willems B, Deschenes M, Hilzenrat N, Mousseau R, Sabbah S. Use of sequence analysis of the NS5B region for routine genotyping of hepatitis $C$ virus with reference to $C / E 1$ and $5^{\prime}$ untranslated region sequences. J Clin Microbiol. 2007:45:1102-12.

207. Bukh J, Miller RH, Purcell RH. Genetic heterogeneity of hepatitis C virus: quasispecies and genotypes. Semin Liver Dis. 1995:15:41-63.

208. McOmish F, Yap PL, Dow BC, Follett EA, Seed C, Keller AJ, Cobain TJ, Krusius T, Kolho E, Naukkarinen R, et al. Geographical distribution of hepatitis C virus genotypes in blood donors: an international collaborative survey. J Clin Microbiol. 1994;32:884-92.

209. Fu Y, Qin W, Cao H, Xu R, Tan Y, Lu T, Wang H, Tong W, Rong X, Li G, et al. HCV 6 a prevalence in Guangdong province had the origin from Vietnam and recent dissemination to other regions of China: phylogeographic analyses. PLoS One. 2012;7:e28006.

210. Lu L, Nakano T, He Y, Fu Y, Hagedorn CH, Robertson BH. Hepatitis C virus genotype distribution in China: predominance of closely related subtype $1 \mathrm{~b}$ isolates and existence of new genotype 6 variants. J Med Virol. 2005;75:538-49. 
211. Wang Y, Xia X, Li C, Maneekarn N, Xia W, Zhao W, Feng Y, Kung HF, Fu Y, Lu L. A new HCV genotype 6 subtype designated $6 \mathrm{v}$ was confirmed with three complete genome sequences. J Clin Virol. 2009;44:195-9.

212. Xia X, Lu L, Tee KK, Zhao W, Wu J, Yu J, Li X, Lin Y, Mukhtar MM, Hagedorn $\mathrm{CH}$, Takebe $\mathrm{Y}$. The unique HCV genotype distribution and the discovery of a novel subtype $6 \mathrm{u}$ among IDUs co-infected with HIV-1 in Yunnan, China. J Med Virol. 2008;80:1142-52.

213. Xia X, Zhao W, Tee KK, Feng Y, Takebe Y, Li Q, Pybus OG, Lu L. Complete genome sequencing and phylogenetic analysis of HCV isolates from China reveals a new subtype, designated 6u. J Med Virol. 2008;80:1740-6.

214. Xu R, Tong W, Gu L, Li C, Fu Y, Lu L. A panel of 16 full-length HCV genomes was characterized in China belonging to genotypes 1-6 including subtype $2 f$ and two novel genotype 6 variants. Infect Genet Evol. 2013;20:225-9.

215. Su Y, Liu H. Hepatitis c virus genotype distribution in China. Chin J Epidemiol. 2013;34:80-4.

216. Zhang C, Wu N, Liu J, Ge Q, Huang Y, Ren Q, Feng Q, He G. HCV subtype characterization among injection drug users: implication for a crucial role of Zhenjiang in HCV transmission in China. PLoS One. 2011;6:e16817.

217. Dong ZX, Zhou HJ, Wang JH, Xiang XG, Zhuang Y, Guo SM, Gui HL, Zhao GD, Tang WL, Wang $H$, Xie Q. Distribution of hepatitis $C$ virus genotypes in Chinese patients with chronic hepatitis C: correlation with patients' characteristics and clinical parameters. J Dig Dis. 2012;13:564-70.

218. Nie H, Chen J. Hepatitis $\mathrm{c}$ virus genotype distribution of research on Chinese han population with chronic HCV infection. Chin J Epidemiol. 2012;33:501-4.

219. Ge X, Wang S, Li D, Mizokami M, Wu R, Huang G, Li Y, Wang Y, Wang Y, Cao $K$, et al.: Molecular biology research on HCV serologica genotype and suntypes in IDUs, patients and blood donors in Guangxi. The experimental and clinical virology journal 1996;2:312-317.

220. Chen YD, Liu MY, Yu WL, Li JQ, Peng M, Dai Q, Liu X, Zhou ZQ. Hepatitis C virus infections and genotypes in China. Hepatobiliary Pancreat Dis Int. 2002;1:194-201.

221. Wang y, Chen c: Hepatitis c genotyping and clinical significance In The fifth national clinical liver disease and the tenth anniversary of the founding of the Chinese journal of liver disease academic conference proceedings. 2006

222. Yuen MF, Lai CL. Response to combined interferon and ribavirin is better in patients infected with hepatitis C virus genotype 6 than genotype 1 in Hong Kong. Intervirology. 2006;49:96-8.

223. Xu R, Wang M, Qiu Y. C: Hepatitis c virus (HCV) infection with different genotypes in China. Chinese Journal of Viral Diseases 2015;5:11-16.

224. Wang J, Tang S: HCV genotyping among HCV patients with different transmission routs. China Public Health. 2013;29:809-811.

225. Chen W, Nie J, Cai W, Yuan X, Hu F, Wei S, Tang Y, Zhnag F, Tang X. Analysis of HCV genotyping among patients infected with single HCV and HIV/HCV. Chin J Liver Dis. 2011;19:729-33.

226. Zhao R, Peng J, Tang L, Huang H, Liu M, Kong W, Pang B. Epidemiological distribution and genotype characterization of hepatitis $C$ virus and HIV coinfection in Wuhan, China, where the prevalence of HIV is low. J Med Virol. 2013;85:1712-23.

227. Li WQ, Yuan ZH, Xu GH, Wu DL. Hepatitis c genotyping progress and its clinical significance. World Chinese Journal of Digestology. 2009;17:589-593.

228. Lu L, Wang M, Xia W, Tian L, Xu R, Li C, Wang J, Rong X, Xiong H, Huang K, et al. Migration patterns of hepatitis $C$ virus in China characterized for five major subtypes based on samples from 411 volunteer blood donors from 17 provinces and municipalities. J Virol. 2014;88:7120-9.

229. Huang JT, Xia R, Xiong HP, Xu R, Huang K. Correlation study of HCV genotype and viral load among voluntary blood donors in Guangzhou. Chinese journal of blood transfusion. 2012;28:1063-1065.

230. Chen J, He YC. genotyping characteristics and significance in Maintenance hemodialysis patients infected with hepatitis c virus. Chinese Journal of Blood Purification. 2013;12:282-286

231. Yang JY, Ye XL, Cheng SQ. Some questions on HCV genotype in patients transmitted by hemodialysis. Chinese Journal of Viral Diseases. 2014:4:235-239.

232. Ye Y. Hepatitis c epidemic characteristics in fujian province and the construction and application of cell culture model in vitro. Doctor. Fujian Medical University. 2011.

233. Simmonds $P$. Reconstructing the origins of human hepatitis viruses. Philos Trans R Soc Lond B Biol Sci. 2001;356:1013-26.

234. Xiong T, Hu AR, Jiang SW, Ding SX. Correlation analysis of HCV genotype and viral load and disease progression. Disease Surveillance. 2015;30:19-22.

235. Li Z: HCV genotype and subtype research among $78 \mathrm{HCV}$ infectors in Urumchi. Master. Xinjiang Medical University. 2010.
236. Chakravarti A, Dogra G, Verma V, Srivastava AP. Distribution pattern of HCV genotypes \& its association with viral load. Indian J Med Res. 2011 133:326-31.

237. Huang JT, Xiong HP, Xu R, Huang K, Wang M, Fu YS. The correlation analysis of HCV genotype viral load among voluntary blood donors in Guangzhou. Chinese Journal of Blood Transfusion. 2012;25:1063-1065.

238. Yue QH, Zhang XQ, Shang Y, Chen YZ, Sun WL, Su MQ, Mu SJ, Hao XK, Hu $X B$. Anti-HCV reactive volunteer blood donors distribution character and genotypes switch in Xi'an, China. Virol J. 2010;7:186.

239. Rong $X$, Lu L, Wang J, Xiong H, Huang J, Chen J, Huang K, Xu R, Wang M, Zhang $X$, et al. Correlation of viral loads with HCV genotypes: higher levels of virus were revealed among blood donors infected with 6 a strains. PLoS One. 2012;7:e52467.

240. Kryczka W, Brojer E, Zarebska-Michaluk D, Medynska J, Urbaniak A. Factors influencing natural history of chronic hepatitis C. Med Sci Monit. 2001;7 Suppl 1:212-6.

241. Riaz S, Bashir MF, Haider S, Rahid N: Association of genotypes with viral loadand biochemical markers in HCV-infected Sindhi patients. Braz J Microbiol 2016:47:980-986

242. Ali A, Nisar M, Ahmad H, Saif N, Idrees M, Bajwa MA. Determination of HCV genotypes and viral loads in chronic HCV infected patients of Hazara Pakistan. Virol J. 2011;8:466.

243. Ali IM, R A: Distribution pattern of HCV genotypes and its significance with viral load. IJMRHS 2013, 2:569-576

244. Liang YD, Yang XL, Zhang L, Xiong JF, Hong ZP, Huang H. The correlation analysis of HCV genotype and viral load and Biological cytology index in serum/blood in Guiyang. Guizhou Medical Journal. 2015;39:14-17.

245. Nie HM, Chen JJ, Dong HL. Analysis of clinical characteristics of the infection of HCV genotype 1 and non-genotype 1 in China. Journal of Clinical Hepatology. 2012;28:439-442.

246. Wiley TE, Brown J, Chan J. Hepatitis C infection in African Americans: its natural history and histological progression. Am J Gastroenterol. 2002;97: 700-6.

247. Lee CM, Hung $\mathrm{CH}$, Lu SN, Wang JH, Tung HD, Huang WS, Chen CL, Chen WJ, Changchien CS. Viral etiology of hepatocellular carcinoma and HCV genotypes in Taiwan. Intervirology. 2006;49:76-81.

248. Xie $Y$, Xie $C$. The research progress of hepatitis $c$ virus genotyping. Journal of Dalian Medical University. 2010;32:470-474.

249. Wang L, Xu DP, Zhang LX. HCV genotyping and clinical significance. Hepatology. 2006;11:416-417.

250. Poynard T, Ratziu V, McHutchison J, Manns M, Goodman Z, Zeuzem S, Younossi Z, Albrecht J. Effect of treatment with peginterferon or interferon alfa-2b and ribavirin on steatosis in patients infected with hepatitis $C$. Hepatology. 2003;38:75-85.

251. Farci $P$, Purcell RH. Clinical significance of hepatitis $C$ virus genotypes and quasispecies. Semin Liver Dis. 2000;20:103-26.

252. Rao HY, Sun DG, Yang RF, Liu F, Wang J, Feng B, Wu N, Fang JL, Song GJ, $\mathrm{Ma} \mathrm{H}$, et al. Outcome of hepatitis $C$ virus infection in Chinese paid plasma donors: a 12-19-year cohort study. J Gastroenterol Hepatol. 2012;27:526-32.

253. Lee CM, Hung CH, Lu SN, Changchien CS. Hepatitis C virus genotypes: clinical relevance and therapeutic implications. Chang Gung Med J. 2008:31:16-25.

254. Xu K, Deng XZ. HCV genotyping in Yixing, Jiangsu Province. Chinese Journal of Epidemiology. 2005;26:73-75.

255. Kanwal F, Kramer JR, llyas J, Duan Z, El-Serag HB. HCV genotype 3 is associated with an increased risk of cirrhosis and hepatocellular cancer in a national sample of U.S. Veterans with HCV. Hepatology. 2014;60:98-105.

256. Larsen C, Bousquet V, Delarocque-Astagneau E, Pioche C, Roudot-Thoraval F, Committee HCVSS, Group HCVS, Desenclos JC. Hepatitis C virus genotype 3 and the risk of severe liver disease in a large population of drug users in France. J Med Virol. 2010;82:1647-54.

257. Dua A, Desai SS, Kumar N, Heller J. Epidemiology and treatment strategies of iliac vein thrombophlebitis. Vascular. 2015;23:599-601.

258. Fried MW, Shiffman ML, Reddy KR, Smith C, Marinos G, Goncales Jr FL, Haussinger D, Diago M, Carosi G, Dhumeaux D, et al. Peginterferon alfa-2a plus ribavirin for chronic hepatitis C virus infection. N Engl J Med. 2002;347:975-82.

259. Zhao S, Liu E, Yu H, Yang H, Xun M, Xue X, Song J, Xu K, Chu Y. Comparison of peginterferon and interferon in treating Chinese patients with chronic hepatitis C. Hepatogastroenterology. 2008;55:1047-54.

260. Bi MR, Kang L, Zhang K, Yang BS: Clinical significance of different HCV genotypes and discussion about treatment effect of interferin. Chinese Journal of Frontier Medical Science. 2015;7:76-79. 
261. Omata M, Kanda T, Yu ML, Yokosuka O, Lim SG, Jafri W, Tateishi R, Hamid SS, Chuang WL, Chutaputti A, et al. APASL consensus statements and management algorithms for hepatitis $\mathrm{C}$ virus infection. Hepatol Int. 2012:6:409-35.

262. Ghany MG, Nelson DR, Strader DB, Thomas DL, Seeff LB, American Association for Study of Liver D. An update on treatment of genotype 1 chronic hepatitis C virus infection: 2011 practice guideline by the American Association for the Study of Liver Diseases. Hepatology. 2011;54:1433-44.

263. Saito T, Ito T, Ishiko H, Yonaha M, Morikawa K, Miyokawa A, Mitamura K. Sequence analysis of PePHD within HCV E2 region and correlation with resistance of interferon therapy in Japanese patients infected with HCV genotypes 2a and 2b. Am J Gastroenterol. 2003;98:1377-83.

264. Hazari S, Taylor L, Haque S, Garry RF, Florman S, Luftig R, Regenstein F, Dash S. Reduced expression of Jak-1 and Tyk-2 proteins leads to interferon resistance in hepatitis C virus replicon. Virol J. 2007:4:89.

265. Afzal S, Idrees M, Akram M, Awan Z, Khubaib B, Aftab M, Fatima Z, Badar $\mathrm{S}$, Hussain A. Mutations in the E2-PePHD region of hepatitis $C$ virus genotype-3a and correlation with response to interferon and ribavirin combination therapy in Pakistani patients. Virol J. 2010;7:377.

266. Taylor DR, Shi ST, Romano PR, Barber GN, Lai MM. Inhibition of the interferon-inducible protein kinase PKR by HCV E2 protein. Science. 1999; 285:107-10.

267. Feeney ER, Chung RT. Antiviral treatment of hepatitis C. BMJ. 2014;348:g3308.

268. Pawlotsky JM. New hepatitis $C$ therapies: the toolbox, strategies, and challenges. Gastroenterology. 2014;146:1176-92.

269. Lee R, Kottilil S, Wilson E. Sofosbuvir/velpatasvir: a pangenotypic drug to simplify HCV therapy. Hepatology International, 2016:1-10.

270. Antón J M M. Abstracts of the 25th Annual Conference of APASL, February 20-24, 2016, Tokyo, Japan. Hepatology International, 2016;10:1-506.

271. Gan XM, Li W. Opportunities and challenges of HCV treatment. Journal of kunming medical university. 2014;35:1-3.

\section{Submit your next manuscript to BioMed Central and we will help you at every step:}

- We accept pre-submission inquiries

- Our selector tool helps you to find the most relevant journal

- We provide round the clock customer support

- Convenient online submission

- Thorough peer review

- Inclusion in PubMed and all major indexing services

- Maximum visibility for your research

Submit your manuscript at www.biomedcentral.com/submit 